\title{
Care of adolescents sheltered in maternity hospitals from the perspective of health professionals*
}

\author{
Assistência às adolescentes abrigadas em maternidade sob a ótica de profissionais de saúde \\ Asistencia a las adolescentes albergadas en una maternidad bajo la óptica de profesionales de salud
Lucia Helena Garcia Penna ${ }^{1}$, Raquel Fonseca Rodrigues ${ }^{2}$, Valéria Aliprandi Lucido $^{3}$, Claudia Rosane Guedes ${ }^{4}$, Licia Maria Accioly Lima ${ }^{5}$

\begin{abstract}
Objective: Discuss determinant aspects of quality care of pregnant adolescents sheltered in a maternity hospital, according to the perspective of health professionals. Methods: Study with a qualitative, exploratory approach, conducted in a maternity hospital in the Municipality of Rio de Janeiro - RJ, reference for sheltered youngsters. The subjects of the study were 14 health professionals. The data were treated according to the Content Analysis technique. Results: Two categories of analysis emerged: Characteristics of care provided by health professionals at the maternity hospital directed towards the sheltered adolescent mother and her child; Characteristics of the organization/structure of the maternity hospital that affected the care of the sheltered pregnant adolescents. Conclusion: It is necessary to incorporate the guiding practices of integrality/interdisciplinarity into the service. The stigmatization of these youngsters is one of the greatest challenges to full assistance and care. The maternity hospital space is a rich environment for the nurse-adolescent dialogic process.
\end{abstract}

Keywords: Quality of health care; Health personnel; Women's health; Pregnancy in adolescence; Adolescent, institutionalized

\section{RESUMO}

Objetivo: Discutir aspectos determinantes de uma assistência de qualidade a adolescentes grávidas, abrigadas em uma maternidade, conforme a ótica de profissionais de saúde. Métodos: Estudo de abordagem qualitativa, exploratório, realizado em uma maternidade do Município do Rio de Janeiro - RJ, referência para jovens abrigadas. Foram sujeitos do estudo 14 profissionais da equipe de saúde. Os dados foram tratados, conforme a técnica da análise de conteúdo. Resultados: Duas categorias de análise emergiram: Características do atendimento dos profissionais de saúde da maternidade direcionadas à mãe adolescente abrigada e seu filho; Características da organização/estrutura da maternidade que afetam o atendimento às adolescentes abrigadas grávidas. Conclusão: Faz-se necessário incorporar as práticas norteadoras da integralidade/ interdisciplinaridade do serviço. A estigmatização destas jovens significa um dos maiores desafios à assistência e ao cuidado integral. $\mathrm{O}$ espaço da maternidade configura um rico ambiente para processo dialógico enfermeiro-adolescente.

Descritores: Qualidade da assistência à saúde; Pessoal de saúde; Saúde da mulher; Gravidez na adolescência; Adolescente institucionalizado

\section{RESUMEN}

Objetivo: Discutir aspectos determinantes de una asistencia de calidad a adolescentes embarazadas, albergadas en una maternidad, conforme la óptica de profesionales de salud. Métodos: Estudio de abordaje cualitativo, exploratorio, realizado en una maternidad del Municipio de Rio de Janeiro - RJ, referencia para jóvenes albergadas. Los sujetos del estudio fueron 14 profesionales del equipo de salud. Los datos fueron tratados, conforme a la técnica del análisis de contenido. Resultados: Emergieron del análisis dos categorías: Características de la atención de los profesionales de salud de la maternidad direccionadas a la madre adolescente albergada y su hijo; Características de la organización/estructura de la maternidad que afectan la atención a las adolescentes albergadas embarazadas. Conclusión: Se hace necesario incorporar las prácticas norteadoras de la integralidad/interdisciplinaridad del servicio. La estigmatización de estas jóvenes significa uno de los mayores desafíos a la asistencia y al cuidado integral. El espacio de la maternidad configura un rico ambiente para el proceso dialógico enfermero-adolescente.

Descriptores: Calidad de la atención de salud; Personal de salud; Salud de la mujer; Embarazo en adolescencia; Adolescente institucionalizado

\footnotetext{
* Study conducted at the State University of Rio de Janeiro - UERJ, developed in a Maternity Hospital of the national health system SUS, located in the central region of the municipality of Rio de Janeiro, (RJ), Brazil.

${ }^{1}$ Doctor of Nursing. Adjunct Professor of the Department of Mother Infant Nursing and of the Post Graduate Program of the School of Nursing at the State University Rio de Janeiro - UERJ- Rio de Janeiro (RJ), Brazil.

${ }^{2}$ Doing Post Graduate Studies (Doctorate) in the Post-Graduation Program of the School of Nursing, State University of Rio de Janeiro - UFRJ-Rio de Janeiro (RJ), Brazil.

${ }^{3}$ Doing Post Graduate Studies (Master's) in the Post-Graduation Program of the School of Nursing, State University of Rio de Janeiro - UFRJ-Rio de Janeiro (RJ), Brazil.

${ }^{4}$ Master of Nursing in the Post-Graduation Program of the School of Nursing, State University of Rio de Janeiro - UFRJ - Rio de Janeiro (RJ), Brazil.

${ }^{5}$ Doing Post Graduate Studies (Master's) in the Post-Graduation Program of the School of Nursing, State University of Rio de Janeiro-UFRJ-Rio de Janeiro (RJ), Brazil.
} 


\section{INTRODUCTION}

Adolescence is a stage replete with peculiarities which, when added to the diverse characteristics that permeate care of adolescents, may become determinant in the quality of health care offered at the various levels of health care services.

One of the challenges in care of the adolescent may be pointed out as being the need for suiting the language and form of action of the professionals to this specific situation. In the last two decades health care of the adolescent has also become one of the priorities in international institutions for research funding. This is due to the finding that the upbringing and lifestyle of adolescents is crucial, not only to them, but to future generations as well ${ }^{(1)}$.

With respect to pregnancy in adolescence, if we consider these young women as holders of a complex triad of vulnerability: being an adolescent, sheltered/ without family backupand pregnant, the difficulties with health care are easily potentiated. The process of intensification of vulnerability culminates in the figure of the adolescent without family backup as one of the axes of her relational inclusion ${ }^{(2)}$. Thus, there is need for a policy for these youngsters, which considers all these factors, however, without homogenizing and simplifying the adolescent's health ${ }^{(3)}$.

The Statute of the Child and Adolescent - ECA ("Estatuto da Criança e do Adolescente), in an attempt to sediment health practices that meet the demands and particularities of adolescents and that in fact promotes care directed towards this group, recommends that: the pregnant adolescent receives pre- and perinatal care, by intermediary of the national health service, SUS ("Sistema Único de Saúde") making use of universal access to and egalitarian care of the actions and services for the promotion, protection and recovery of health. It should be pointed out that no child or adolescent should be the object of any type of neglect, violence or discrimination ${ }^{(4)}$. The General Guidelines for the Implementation of the Humanization Program emphasize the characteristics necessary for care of the adolescent based on quality and integrality: reinforcment of the concept of extended clinic with commitment to the subject and his/her collective group, stimulation of different therapeutic practices and co-responsibility of the managers, workers and users in the process of health production; raising the sensitivity of the health teams to the problem of intrafamily violence, the question of prejudices (sexual, racial, religious and others); suiting the services to the local environment and culture, respecting the privacy and promoting a favorable reception and comfort- able ambience; guarantee of continuity of care with a system of reference and counter reference, and a permanent educational plan for workers with humanization themes ${ }^{(5)}$.

In view of the particularities of this group and the characteristics that care may assume, the object was traced of discussing the determinant aspects of quality care for sheltered pregnant adolescents in a maternity hospital, according to the perspective of health professionals.

\section{METHODS}

Research of a qualitative, exploratory nature, developed in a Maternity Hospital of the national health system SUS, located in the central region of the municipality of Rio de Janeiro, reference for young pregnant women in shelter facilities.

This research is an extract of a larger study that analyzed the structure of maternity support for sheltered adolescents in the Municipality of Rio de Janeiro, and collected data in various scenarios - shelters, Municipal Health Centers and the mentioned Maternity hospital. Thus the interviews were held in sequence and numbered from 01 to 20 .

Data collection occurred between May and June 2010. Fourteen health professionals from the unit were interviewed: 6 nurses, 4 nursing technicians and 4 doctors. $O$ the total number of professionals interviewed, 12 declared that they had no qualification course directed towards the adolescent public, and 2 declared having taken a training course directed towards care with reference to breastfeeding.

To begin with data collection, a form with questions to identify the subjects was used. After this, a script was used to hold the semi-structured interview composed of six open questions, which was recorded and transcribed afterwards, paying attention to the faithfulness of the statements. These interview were previously scheduled at a time and place determined by the interviewee.

The ethical demands for researches involving human beings were complied with, and the research project was approved by the Research Ethics Committee of the Municipal Secretary for Health of Rio de Janeiro Protocol No. 73A/09. Participation of all subjects was voluntary and authorized by means of signature of the Term of Free and Informed Consent.

The data collected were analyzed by means of the thematic modality of content analysis ${ }^{(6)}$. From this process, two thematic categories emerged, which will be presented as follows, and will be divided into intermediate sub-categories. 


\section{RESULTS}

In their statements about the care provided in the maternity hospital, the health professionals pointed out different points of view, not only with respect to the psycho-social aspects of the professionals involved in this care, but also as far as the structural aspects of the unit in question are concerned.

\section{Characteristics of care provided by health professionals at the maternity hospital to the sheltered adolescent mother and her child}

\section{Favorable Personal Conditions}

The health professionals interviewed characterized the care provided in a positive manner, when they demonstrated in their discourses, their ability to have an interpersonal relationship with the sheltered adolescents who were hospitalized in the health unit together with their children. This interpersonal skill appears clearly in their statements, by means of characteristics that demonstrated a favorable personal condition for providing care: sensitive dialogue/listening skill; approximation to the adolescent, seeking to engage in the same language; equality in the care of sheltered adolescents; good relationship with these adolescents and availability for working with this group.

It was possible to identify the establishment of dialogues between the health professionals and sheltered adolescents with the help of sensitive listening: Try to listen when they need something, some explanation (...) about the pregnancy itself or the base disease they may have (...) (E13)

We perceived that in addition to this sensitive listening, the professionals tried to reach an approximation to the sheltered adolescents, by means of a similar, almost playful language, and establishment of a good relationship with them: [Depending on the clientele's profile] Am I only going to change the way I express myself? But, trying to get closer to her. When she comes closer in this way, and is already very close, then I change my discourse as well. (E07)

The health professionals emphasized their availability to deal with this group, which could be understood as an important facilitating factor in providing the care: But I have no problem whatever. (...) I have never had any problem with any adolescent whether she was in the shelter, or even if she were a street dweller. (E17)

Therefore, it was possible to say that the characteristics mentioned added to equality in the care provided is going to contribute to the construction of quality care of this social group that is frequently resistant to approximation and stigmatized: Thus we have no one, no one who makes a distinction or differentiation in the care provided, by the very essence that maternity is in this sense. We take care of them in an equal manner. (E09)

\section{Unfavorable Personal Conditions}

Some of the interviewees demonstrated difficulties with caring for these adolescents due to personal characteristics such as impatience or the difficulty in adopting a more accessible language when dealing with these girls: One does one's best. But, at times one really gets impatient (...). (E15).

We also found one interviewee who attributed this difficulty to the aggressive attitudes of the sheltered adolescents. Nevertheless, the interviewee pondered about her availability in the work, when she understood that it did not concern a "personal aggression", but a reaction that originated from the way of life crossed by violence towards the adolescents: It is verbal aggression, you understand? I have come across girls here, I don't know whether they came from the shelter, who called me the jailer (...) How can one not understand? That is the environment in which she lives! I am not a jailer (...) I go there and attend to her. [reference to the aggressive way of expressing herself] (E07)

Another point that prevent the construction of quality care is the discriminatory and/or prejudiced attitudes towards the sheltered mother-child binomial, particularly because they relate the sheltered adolescents to the use of drugs, and the condition of living on the street/or in a shelter, and lastly, by the entire historical-social construction of sheltering: (...) the staff advise beforehand," so-and-so bed $x$ is from a shelter". I go and look at the record chart. So-and-so is a drug user, So-and-so is this, So-and-so is that, she has already had so-many children. (...) she is labeled. (E10).

Only one interviewee reflected and recognized that the discriminatory attitude ends up compromising the quality of the care provided: Does that adolescent, in addition to be a pregnant adolescent, now become a sheltered pregnant adolescent? Then her point of view is really very loaded, and unfortunately this ends up spilling over into the quality of care.(E19)

As previously mentioned, we understand the need to deconstruct this stigmatized view in order to enable the transforming care to be achieved. However, we are faced with the difficulty of arousing the sensitivity of the professionals: There is still a great deal of stigma, discrimination. This is something that is so difficult to deconstruct. (E16).

Characteristics of the Organization/Structure of the maternity hospital that interfere in the care of sheltered pregnant adolescents.

In their discourses the professionals indicated the organization of the health unit as factors influencing the action and qualification of care provided for the sheltered adolescent and her child, and presented suggestions for improving the care provided. 
The Professional's action in the Health Unit

Among the health actions, we perceived that the Social Service is mentioned with great frequency as being responsible for resolving the problems that involve sheltered adolescents and their children, signifying a transfer of this problem. The Social Service is taken as the only one that knows the sheltering system, and consequently, the only one capable of solving the problems that emerge: So I think that training to deal with the social part must be done in the Social Service. (E20).

On the other hand, some interviewees bring into their statements aspects that denote multidisciplinary actions in an interdisciplinary trial among the professionals of the teams involved in caring for sheltered adolescents: One tries to link ..the social assistant, mental health...a little, even to know how the adolescent's return to the shelter will be, and what this reception will be like. (E16).

Moreover, within the health actions, we point out those relative to performing exams/providing care as effective practice of the service offered, in which the health professionals become facilitator agents for carrying out these actions: One has to do this work right from the start. When the pregnant adolescent comes here (...) we begin right from the first consultation, schedule nutrition, refer them to the dental service. (E09)

When the interviewees approached the reference and counter-reference system of health care of the sheltered adolescent at the hospital unit, they pointed out the health professionals as facilitator agents, both in the adolescents' post-discharge period, in case of a need to return to the unit, and when they are referred to outside units: (...) we have some places. For example, a certain unit that does that exam. So we get in touch with the unit and schedule it. (E09);

The maternity professionals involved with the sheltered adolescents also end up playing their role as educators, since they offer reproductive and sexual health guidance to this group. They receive guidance as regard the development of the body, sexuality and contraceptive methods: The sheltered adolescent? Thus... one ends up trying to reach... You try... to counsel, speak... (E11). And also, guidance about gestation (pre-natal, birth and post-partum): One explains everything there is to explain about breastfeeding, about care of the baby ... Every day we explain. (E17).

\section{Quality care of sheltered adolescents at the health unit}

As regards care of the sheltered adolescents and their children, the health professionals qualify the care provided in a satisfactory manner when they described the attitudes of the professionals involved in this care when receiving the adolescents: Ob yes, professional care! (...) as the service already has a section that provides assistance to the adolescent, it is a tradition within the bealth of the municipality. All who enter here, already perceive this type of mentality. (E09)

Furthermore, qualifying the care provided in a satisfactory manner, the professionals mention the resources available at the health unit: There are two infirmaries specifically for the adolescents, as recommended... Where they stay with the companions from the time they are hospitalized until they are discharged. (E19).

Nevertheless, the care of sheltered adolescents and their children becomes unsatisfactory when one perceives various negative aspects in the statements of the professionals. Among them, the lack of knowledge/ lack of professional training for caring for sheltered adolescents; the lack of specific care of the adolescent mothers and lack of investment in multiprofessional care and the lack of resources of the health institute for meeting the needs of the sheltered adolescents: There is lack of a more specific care for the adolescents]. If she needs a more specific reception or care, one is going to need to be trained for this. (E13); There is explicit need for a greater knowledge of the sheltering system with regard to health care in order to improve the quality of care provided within the maternity hospital: (...) I am not sure about the ambulatory clinic part, whether they are referred to this maternity hospital by the shelter to receive pre-natal care, or whether they undergo their pre-natal care elsewhere and afterwards, when they go into labor, they come here... (E17); When they leave here, they don't go to their homes. They go to the shelter, and I also don't know whether the baby stays with them at the shelter, of whether it goes to an institution ... for adoption. I don't know how it works (E17).

With respect to the difficulty of multiprofessional interaction, this appears to be a factor that makes care difficult at the maternity hospital in question: (...) my job is to make an obstetric visit. (E14); (...) each one acts in her own area. The social part is performed by social service, you understand? (E20).

Finalizing this category, we present some of the aspects that emerged as suggestions to improve the care provided to the sheltered adolescent, among them: qualification, consciousness-raising and psychological support: I believe that in order to work with adolescents you need a qualification/training. (E19); (...) it is to make the professional aware!. (E14).

\section{DISCUSSION}

The care of sheltered adolescents is still filled with stigmas and common sense, fruit of the entire historical-social construction connected with sheltering, which ends up compromising the quality of the care provided. We may consider this barrier a question of attitude on the part of health professionals, as a significant agent making care difficult, in line with the ECA which establishes that no child or adolescent should be the object 
of any form of neglect or discrimination. Situations of institutionalization frequently stigmatize, leading to consequences for physical and mental health, and the social insertion of those who go through it ${ }^{(4,7)}$.

The existent stereotypes about poor childhood and adolescence may mean an inversion of the approach impregnated with stigmas in their daily lives - in this case, in their reproductive health care, creating immutable and banalized myths that generate a situation of indifference to the magnitude of the problem, in addition to interfering in the fulfillment of social policies ${ }^{(8)}$.

On the other hand, the health professionals involved with sheltered pregnant adolescents may develop skills for care and interpersonal relationships with this group, in the form of personal and/or institutional ties, which are important facilitators of care. By establishing these ties, we would be able to evaluate their risks, vulnerabilities, limits, motivations and possibilities, thereby increasing the conditions for us to provide full and quality care ${ }^{(9)}$. In addition, in spite of the designed professional-patient relationship - a possible constructor of ties, the professionals interviewed did not recognize themselves as transforming agents of the subjects under discussion. The institutions must assume a commitment to break with the "culture that makes a thing" of this vulnerable youngster, freeing itself of "prejudices" and "common sense", removing this youngster from the condition of being an object, subject to violence, and elevating her to the condition of being the author of her own story, which necessarily implies a change in values, ideas and conducts ${ }^{(1)}$.

The role of nursing professionals becomes fundamental in the face of this context of exclusion and marginalization. The actions of nursing are directly linked to the subject, and may contribute to the construction of the identity of these youngsters who are sheltered/ without family ties. For this subject, especially, care requires sensitivity, opening, partnerships, but above all, the predisposition to create ties ${ }^{(10)}$. It is emphasized that "The professional needs to like adolescents, because they have an extraordinary sensitivity for identifying rejection"'(11).

Broadening the discussion, the care of these sheltered adolescent mothers is favored by the personal conditions of the health professionals involved, providing integral, dialogical care, and consequently, being a transformer of the other person. Part of what we are is the result of the relationships we are able to establish in our lives, whether they are positive or not ${ }^{(10)}$.

The health professional and client relationship must be permeated by a reflexive dialogical relationship, in which one seeks recognition of one's health-disease process and the perception of being a transforming subject of one's own reality. The nurse gains emphasis in this trajectory, because health education promotes the quality of life by means of articulating technical and popular knowledge, which are multideterminant in the scope of the health-disease-care process ${ }^{(12)}$.

Among the characteristics that are indispensible for attaining transformative care, sensitive listening may provide an approximation to the adolescent, and consequently "break down barriers". It is believed that based on this characteristic dialogue will be established, and the model of medicalized care may be broken.

One cannot lose sight of the fact that equality in care when one is dealing with subjects that are so branded by differences. The construction and implementation of SUS units has guaranteed the precepts of universal, egalitarian and integral access to health care and actions ${ }^{(13)}$. Nevertheless, in practice, the pathways to be trodden towards a just and egalitarian society from the most diverse aspect are tortuous. It is necessary to seek possible articulations, as far as the notion of the value of life and health are concerned in this singular context. Something that allows health action to be not only punctual, but something that serves as an instrument to rescue the values of citizenship and human dignity ${ }^{(14)}$.

Pregnancy can be considered as the thir factor added to the triad of vulnerability experienced by these youngsters. It is necessary to ratify that at the time in which they "gain" yet another factor of vulnerability, the formation of an institutional tie is fundamental, and allows the nurse to play her role as educator. The guidance concerning gestation, the body, sexuality, contraception and care of the newborn are made possible, and draw focus onto the educational actions in reproductive and sexual health.

Commonly, in their academic baggage, nurses bring health education that has been recognized as a promising strategy for facing vulnerability in health and the promotion of quality of life.

Considering the emphasis commonly given to the health actions performed by social services, it is possible to understand the professionals of this area as being mediators between the users and the institution's services, or outside of it, as well as in mediation with other professionals ${ }^{(15)}$. In this study, the actions of social services have been pointed out by the other professionals as fundamental in the relationship between pregnant youngsters, and afterwards puerperae, and the sheltering institute of origin, and by the resolution of problems that emerge during their period of hospitalization. Thereby, this could be seen as a transfer of responsibility of the complex social problem inherent to these youngsters.

In opposition to this "transference, it is clear that some professionals place a value on the actions of social services, understanding them not as the sectors 
responsible for the problem of this stigmatized group, but as a connecting link with the pregnant sheltered girls in a trial of interdisciplinary action.

Within this proposal of multi/interdisciplinarity, when the health professionals mediate in scheduling consultations, exams and procedures among the services offered within the unit, become promoting agents of a quality and resolutive care.

Something similar occurs when one deals with the reference and counter-reference services, as the professionals also assume the role of facilitators in this dual-carriage pathway. Return to the hospitalization unit in the post-partum period, as well as being referred to external services appears to gain an informal nature, as it is implicit that the success and speed of these practices depend largely on interpersonal relationships, rather than on a systematized flow between the levels of care provided ${ }^{(16)}$.

The health professionals qualified the care as satisfactory and unsatisfactory. Satisfactory care was characterized when the professionals observed that the material resources available in the unit and the attitudes during reception favored quality care. Nevertheless, emphasis on a warm reception to care is fundamental, because one cannot lose sight of the fact that pregnancy is a complex experience with each woman facing up to it in a different way. Coping does not have biologic dimensions only, but is also a social process that encompasses the collective society, influencing and being influenced by the family and the environment in which the woman is inserted ${ }^{(17)}$. Therefore, when one is dealing with pregnant, sheltered adolescents, who have lost touch with their family ties, whose collective society gains peculiar denotations and the family is absent, it is necessary to reconstruct the course of their social life. Without reconstructing it, it will be determinant in social dissociation, disqualification and invalidation ${ }^{(2)}$.

In view of this, it is more necessary than ever to provide qualified and humanized care in the pregnancy-puerperal cycle, which occurs by means of conduct involving warm reception, suitable guidance and interdisciplinarity among all the services and levels of care. It is pointed out that the discussion concerning the needs of pregnant adolescents is one of the axes proposed by a warm reception, in which the professionals demonstrate interest in their problems and concerns, and endeavor to seek solutions. Nursing professionals in particular, commonly have tools that favor the creation of a channel of dialogue, in which the cultural values and limitations that involve pregnancy are respected, providing full care for these young women ${ }^{(17)}$.

It is pointed out that the material resources available are facilitators of care, as they interfere in the relationship of the professionals with the administrative elements directly involved in the process of the quality of care. Structures and services suited to the needs of professionals and users result in professional satisfac- tion, and consequently in good care provided by the unit, interfering in the quality of care ${ }^{(18)}$.

Whereas care qualified by the professionals as unsatisfactory involves aspects that highlight the lack of qualification, the unpreparedness of professionals for dealing with and administrating the entire problem that involves this group, lack of interaction among teams and the lack of knowledge of the context of these youngsters' lives. Added to this, the lack of certain resources at the institute was pointed out as a factor causing difficulties.

When we think of quality in nursing, we refer to the use of good materials and equipment, qualified human resources in sufficient numbers, providing full care with an adequate service structure, among other aspects. In the processes of quality of the hospital institutions, the nursing team occupies a fundamental place, as it remains with the persons receiving care for a large part of the time during their hospitalization, promoting maintenance, rehabilitation and recovery of their health, by means of its main resource - care $^{(18)}$.

The interviewees pointed out suggestions predominantly concerned with the importance of qualification and training of professionals to administrate and direct the care towards this very specific group. It is clear that as the end product, the intention of the interviewees was the improvement in care, translated as its quality and integrality. We corroborate that the quality in the institutions may be defined as "continuous improvement with emphasis on the processes and persons marked by principles, ideas and beliefs that ultimately seek the satisfaction of clients and workers" (18).

The study pointed out the need for care with humanized perspective that considers the context of life of these youngsters, since the care that some of the professionals perform continues to be impregnated with prejudices and common sense. We believe that this study may contribute to the deconstruction of this discriminatory and segregating point of view.

We understand that by virtue of the characteristics of the municipality of Rio de Janeiro with all its plurality and singularity, we found ourselves limited to the reality of only one maternity hospital, when the municipality has other ports of entry to receive these pregnant young women. This concerns a punctual reality. We suggest that further studies should be conducted to improve understanding of the reality here discussed.

\section{FINAL CONSIDERATIONS}

It is important to consider that the stigmatization of these youngsters, even when veiled, signifies one of the main factors that make it difficult to provide care with a view to reaching the integrality of the subject, since the distance of the caregiver from the person receiving care raises barriers and nourishes the discriminatory posture. 
The maternity hospital space, period of hospitalization and relationship constructed between the adolescent and health professional, when added together, generate fundamental results: the time of reception, interchange of experiences and formation of institutional and personal ties, configure a rich environment for educational and problem-solving practices, within the nurse-adolescent dialogical process.

For this purpose it is also necessary to have professional qualification, because health actions are facilitated

\section{REFERENCES}

1 Ruzany MA. Atenção à saúde do adolescente: mudança de paradigma. In: Brasil. Ministério da Saúde. Secretaria de Atenção a Saúde. Departamento de Ações Programáticas Estratégicas. Saúde do adolescente: competências e habilidades. Brasília (DF): Ministério da Saúde; 2008. p. 21- 5. (Série B. Textos Básicos de Saúde)

2. Gontijo DT, Medeiros M. [Children and adolescents in street situation: contributions to an understanding of vulnerability and disaffiliation Ciênc Saúde Coletiva. 2009; 14(2):467-75. Portuguese.

3. Ramos FR. Bases para uma re-significação do trabalho de enfermagem junto ao adolescente. In: Associação Brasileira de Enfermagem. Adolescer: compreender, atuar, acolher: Projeto Acolher. Brasília(DF): ABEN; 2001. p. 93-212.

4. Brasil. Presidência da República. Lei n. 8.069, de 13 de julho de 1990. Dispõe sobre o Estatuto da Criança e do Adolescente e dá outras providências. Diário Oficial da República Federativa do Brasil, Brasília(DF); 1990; Jul 17; Seção 1.

5. Brasil. Ministério da Saúde. Secretaria Executiva Núcleo Técnico da Política Nacional de Humanização. Incorporando as contribuições dos grupos de discussão da Oficina Nacional HumanizaSUS. Brasília(DF): Ministério da Saúde; 2004.

6. Bardin L. Análise de Conteúdo. Lisboa: Edições 70; 2010.

7. Ribeiro ND, Constantino, P. Pessoas institucionalizadas e violência. In: Njaine $K$, Assis SG, Constantino P, organizadoras. Impactos da violência na saúde. Rio de Janeiro(RJ): Fundação Oswaldo Cruz; 2009. p. 215-37.

8. Meirelles Z, Herzog R. A violência na vida de adolescentes e jovens In: Brasil. Ministério da Saúde: Secretaria de Atenção a Saúde. Departamento de Ações Programáticas Estratégicas. Saúde do adolescente: competências e habilidades. Brasília(DF): Ministério da Saúde; 2008. p. 129-34. (Série B. Textos Básicos de Saúde).

9. Zuma CE, Mendes CH, Cavalcanti LF, Gomes R. Violência de gênero na vida adulta. In: Njaine K, Assis SG, Constantino $\mathrm{P}$, organizadoras. Impactos da violência na saúde. Rio de when the health professional's sensitivity is aroused. The association of these two factors - qualification and the arousal of sensitivity - broadens the frontiers for a care that truly transforms the other person.

With respect to the peculiarities of care provided for sheltered adolescents in their reproductive process, rather than qualifying health care, there is a latent need for incorporating practices directed by the principles of the policy of humanization, integrality and inter-disciplinarity of the service.

10. Oliveira NS, Medeiros M. [Life histories of girls with experience of life in the streets: perspectives to the inclusion social process]. Rev Eletrônica Enferm [Internet]. 2006 [cited 2012 Jan 12]; 8(1):119-27. Portuguese. Available from: http:/ / www.revistas.ufg.br/index.php/fen/article/view/935

11. Miranda AT, Bouzas IC. Gravidez In: Brasil. Ministério da Saúde. Secretaria de Atenção a saúde: Departamento de Ações Programáticas Estratégicas. Saúde do adolescente: competências e habilidades. Brasília(DF): Ministério da Saúde; 2008. p. 242-56. (Série B. Textos Básicos de Saúde)

12. Souza LB, Torres CA, Pinheiro PN, Pinheiro AK. [Health education practices in Brazil: thinking over the nursing practice Rev Enferm UERJ. 2010; 18(1): 55-60. Portuguese.

13. Brasil. Presidência da República.. Lei n. 8080, de 19 de setembro de 1990. Dispõe sobre as condições para a promoção, proteção e recuperação da saúde, a organização e o funcionamento dos serviços correspondentes e dá outras providências. Diário Oficial da República Federativa do Brasil, Brasília(DF); 1990; Set 20. Seção 1:18055.

14. Carneiro N Jr, Silveira C. [Primary health care organization in the context of social exclusion/inclusion processes]. Cad Saúde Pública. 2003; 19(6):1827-35. Portuguese.

15. Mattoso FA. A dimensão territorial no trabalho do assistente social na estratégia saúde da família. Rev em Pauta. 2009; 24(6):235-51.

16. Juliani CM, Ciampone MH. [Counter-reference and reference system organization in the health system context: nurses' perception]. Rev Esc Enferm USP. 1999; 33(4):323-33. Portuguese.

17. Santos AL, Radovanovic CA, Marcon SS. [Prenatal care: satisfaction and expectations]. Rev Rene. 2010; 11(N Espec):61-71. Portuguese.

18. Silva MJ, Pinheiro EM. Qualidade na assistência de enfermagem - Visão de alunas de especialização. Acta Paul Enferm. 2001; 14(1):82-8. 